\title{
Perbedaan Peran Ibu Primipara Dan Multipara Dalam Pengasuhan Bayi Baru Lahir
}

\author{
Koekoeh Hardjito, Sumy Dwi Antono, Erna Rahma Yani* \\ *Poltekkes Kemenkes Malang Prodi Kebidanan Kediri
}

\begin{abstract}
Primipara mother is woman which has borned a baby aterm the first time. However multipara mother is woman which has been borned life a baby several times but it is not more than five times. Primiparous response as parents need more support from the environment and some women do not like to responsibilities at home and care for the baby. Whereas in multiparous would be more realistic in anticipating his physical limitations and can more easily adapt to the role of social interaction, in the sense of having a positive response as a parent. The role of both in interaction and mothering of newborn baby were observationed either from feeding, interest, respons, speech and touch by FIRST observation method. Many things influencing interaction and ability of mother and mothering baby, one of them are experience of mother bears and takes care of child before it. This research aim to see is there are many difference the role of primipara and multipara mother in mothering of newborn baby that analized with FIRST observation method. Research design used study comparative with design sistematic of random sampling technic for gathering of the sample. Obsevation has been to 53 mother of post partum that consisted of 25 primipara and 28 multipara in Aura Syifa Hospital at Kediri. These observation has been done once between first day up to seventh day after delivering birth. Testing of data was done by Man-Whitney U Test with $p$ value $=0,036(\alpha=0,05)$. The result of research showed there are difference significantly between the role of mother primipara and multipara in mothering of newborn baby. Interaction between mothers with baby and mothering pattern of newborn baby are multipara mother better than primipara mother with FIRST observation method.
\end{abstract}

Key word: the role, primipara, multipara, mothering

\section{Pendahuluan}

Peran orang tua adalah peran berupa tugas dan tanggung jawab orang tua kepada anaknya yang ditujukan untuk mempertahankan kelangsungan hidup anak sekaligus meningkatkan kualitas hidup anak agar mencapai tumbuh kembang optimal baik fisik, mental, emosional maupun sosial serta memiliki intelegensi majemuk sesuai dengan potensi genetiknya (DEPKES RI.2005: 4).

Metoda observasi FIRST adalah suatu metoda observasi yang dilakukan untuk menilai tingkah laku dan respon ibu terhadap bayi baru lahir. Observasi tersebut dikembangkan dalam sisten penilaian yang dibuat sebagai suatu metoda pengukuran aspek-aspek tertentu dari ibu yang mengasuh bayinya yang baru lahir. Lima faktor yang diobservasi adalah Feeding (pemberian makan), Interest (ketertarikan), Response (respon), Speech (berbicara) dan Touch (Sentuhan) disingkat dengan FIRST (Christine $\mathrm{H}$. 2006: 421).

Dalam periode pranatal, ibu adalah satu - satunya pihak yang membentuk lingkungan tempat janin berkembang dan tumbuh. Persatuan simbiosis tertutup antara ibu dan anak berakhir saat bayi lahir (Bobak et al. 2005: 505).

Menjadi orangtua merupakan faktor pematangan dalam diri seorang wanita atau pria dan untuk anak - anak peran orangtua sangat penting (Bobak et al.2005: 505). Tugas, tanggung jawab dan sikap yang membentuk peran menjadi orangtua diharapkan mampu memenuhi kebutuhan dasar anak antara lain: kebutuhan fisis-biomedis (asuh), 
kebutuhan akan kasih sayang/ emosi (asih) dan kebutuhan latihan/ rangsangan/ bermain (asah) supaya anak bisa tumbuh dan berkembang optimal sesuai kemampuannya (IDAI. 2002: 12).

Ikatan ibu dan anak yang erat, mesra, selaras, seawal dan sepermanen mungkin sangatlah penting karena akan turut menentukan perilaku anak di kemudian hari, merangsang perkembangan otak anak dan merangsang perhatian anak kepada dunia luar. Pemenuhan kebutuhan emosi (asih) ini dapat kita lakukan sedini dan seawal mungkin yaitu dengan mendekapkan bayi pada ibunya sesegera mungkin setelah bayi lahir (IDAI. 2002: 12).

Perkenalan, ikatan dan kasih sayang menjadi orangtua yang sering disebut sebagai Bonding Attachment. Lima kondisi yang mempengaruhi ikatan tersebut adalah : kesehatan emosional orangtua, sistem dukungan sosial (meliputi pasangan hidup, teman, keluarga), tingkat ketrampilan dalam berkomunikasi serta dalam memberi asuhan yang kompeten, kedekatan orangtua dengan bayi dan kecocokan orangtua dengan bayi (Mercer (1982) dalam Bobak et al. 2005: 506).

Pada primipara respon sebagai orangtua membutuhkan dukungan yang lebih besar dari lingkungannya dan beberapa wanita tidak suka terhadap tanggung jawab di rumah serta merawat bayi (Bobak et al. 2005: 512). Sedangkan pada multipara akan lebih realistis dalam mengantisipasi keterbatasan fisiknya dan dapat lebih mudah beradaptasi terhadap peran serta interaksi sosialnya, dalam arti mempunyai respon positif sebagai orangtua (Bobak et al.2005: 516). Penelitian yang dilakukan oleh Stewart (1990) dalam Christine (2006: 560) mengidentifikasikan bahwa pertama kali atau kedua kali menjadi orangtua sama sama membuat stres tetapi stres yang dialami pada waktu kedua berbeda dengan stres yang dialami pada waktu pertama menjadi orang tua.
Penelitian oleh O'Hara \& Swain (1996) dalam Handoyo et al. (2007), melaporkan sekitar $13 \%$ wanita melahirkan anak pertama mengalami depresi postpartum pada periode tahun pertama pasca-salin. Depresi postpartum dapat mengakibatkan terjadinya gangguan psikologis jangka pendek dan jangka panjang, tidak saja pada wanita penderita tapi juga pada anak dan anggota keluarga lainnya (Armstrong et al. 2000 dalam Handoyo et al. 2007). Selain itu dapat juga terjadi gangguan hubungan tali kasih ibu dengan anak, kurangnya perhatian ibu dalam merawat, mengasuh serta membesarkan anaknya, kesulitan anak dalam menjalin hubungan sosial dengan lingkungan dan teman sebaya serta konflik perkawinan (Kustjens \& Wolke. 2001 dalam Handoyo et al. 2007). Indriani dalam penelitiannya tentang studi fenomenologi tentang pengalaman ibu primipara dengan keluarga ini dalam merawat bayi baru lahir menyebutkan bahwa merawat bayi sendiri bukan pekerjaan yang mudah, dukungan dari tenaga profesional belum sesuai dengan yang diharapkan. Tujuan penelitian mengetahui perbedaan peran ibu primipara dan multipara dalam pengasuhan bayi baru lahir.

\section{Metode Penelitian}

Desain penelitian yang digunakan dalam penelitian adalah study komparatif. Populasi dalam penelitian ini adalah semua ibu post partum yang bersalin di RS Aura Syifa Kediri dengan sampel sebesar 53 orang terdiri dari 25 ibu primipara dan 28 ibu multipara. Variabel indenpenden dalam penelitian ini adalah ibu Primipara dan ibu Multipara, sedangkan variabel dependen dalam penelitian ini adalah pengasuhan bayi baru lahir. Alat ukur yang digunakan pada penelitian ini berupa lembar observasi dengan skala penilaian (rating scala), yang terdiri dari 5 poin penilaian, yaitu Feeding (pemberian makan termasuk ASI), Interest (ketertarikan) Respons, 
Speech (berbicara termasuk kontak mata) dan Touch (sentuhan) kemudian ditabulasi dalam bentuk skor. Skor terendah 0 dan skor tertinggi 10. Uji statistik yang digunakan adalah Mann Whitney $U$ - Test dengan alpha 0,05 .

\section{Hasil Penelitian}

\section{A. Usia responden}

Berikut keadaan responden menurut golongan usia.

\section{Tabel.1 Usia responden}

\begin{tabular}{ccccc}
\hline Rentang & \multicolumn{2}{c}{ Primipara } & \multicolumn{2}{c}{ Multipara } \\
$\begin{array}{c}\text { Usia } \\
\text { (tahun) }\end{array}$ & frekuensi & Prosentase & frekuensi & Prosentase \\
\hline $15-19$ & 3 & $12 \%$ & 0 & $0 \%$ \\
$20-24$ & 10 & $40 \%$ & 1 & $3,6 \%$ \\
$25-29$ & 11 & $44 \%$ & 4 & $14,3 \%$ \\
$30-34$ & 1 & $4 \%$ & 15 & $53,6 \%$ \\
$35-39$ & 0 & $0 \%$ & 3 & $10,7 \%$ \\
$40-44$ & 0 & $0 \%$ & 5 & $17,8 \%$ \\
\hline Jumlah & 25 & $100 \%$ & 28 & $100 \%$ \\
\hline
\end{tabular}

B. Peran ibu dalam pengasuhan bayi baru lahir

Peran ibu primipara dan multipara dalam pengasuhan bayi baru lahir dikelompokkan dalam kategori baik, cukup dan kurang. Berikut distribusi peran responden :

Tabel 2 Peran ibu Primipara dan Multipara

\begin{tabular}{|c|c|c|c|c|}
\hline \multirow{2}{*}{$\begin{array}{c}\text { Kategori } \\
\text { Peran }\end{array}$} & \multicolumn{2}{|c|}{ Primipara } & \multicolumn{2}{|c|}{ Multipara } \\
\hline & frekuensi & Persen & frekuensi & Persen \\
\hline Baik & 0 & $12 \%$ & 0 & $0 \%$ \\
\hline Cukup & 7 & $28 \%$ & 13 & 46,4 \\
\hline Kurang & 18 & $72 \%$ & 15 & $\begin{array}{c}53,6 \\
0 /\end{array}$ \\
\hline Jumlah & 25 & $100 \%$ & 28 & $100 \%$ \\
\hline
\end{tabular}

C. Prosentase tiap aspek pengamatan pada ibu primipara dan multipara a. Feeding

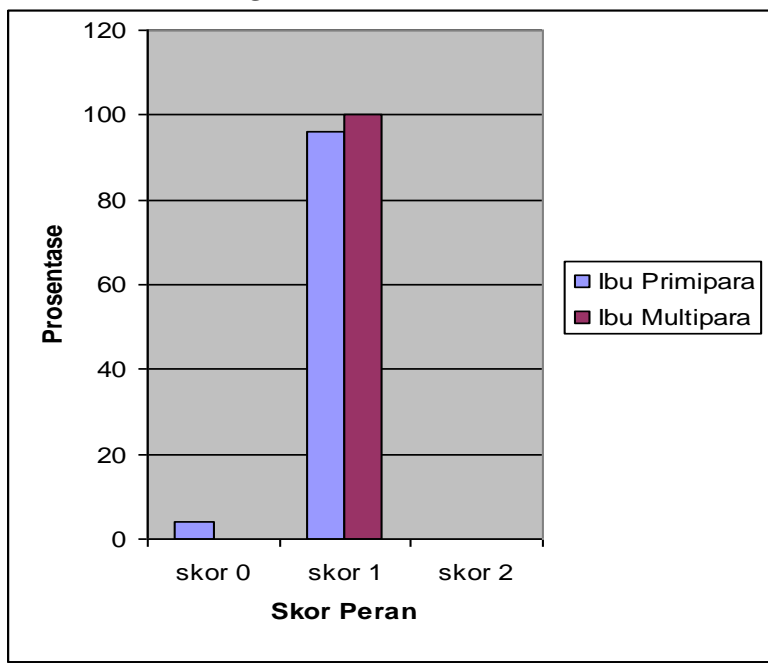

Gambar 1 Prosentase skor aspek Feeding pada ibu Primipara dan Multipara

\section{b. Interest}

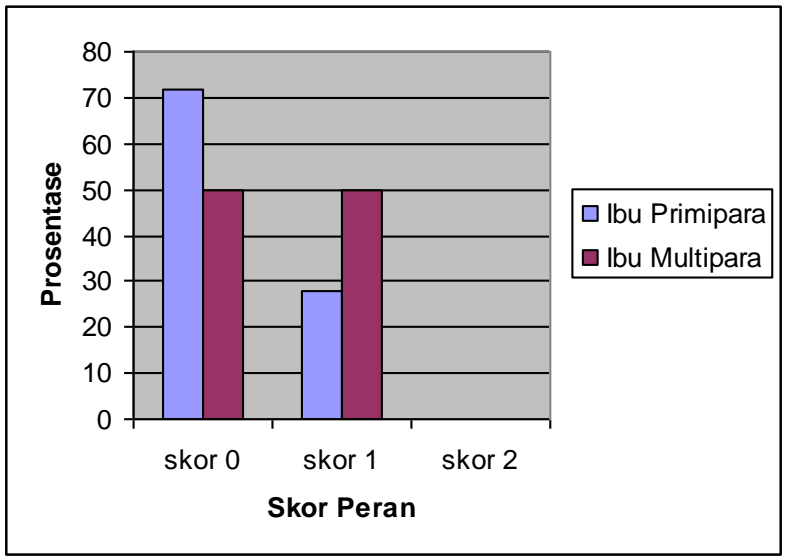

Gambar 2 Prosentase skor aspek interest pada ibu primipara dan multípara

\section{c. Response}

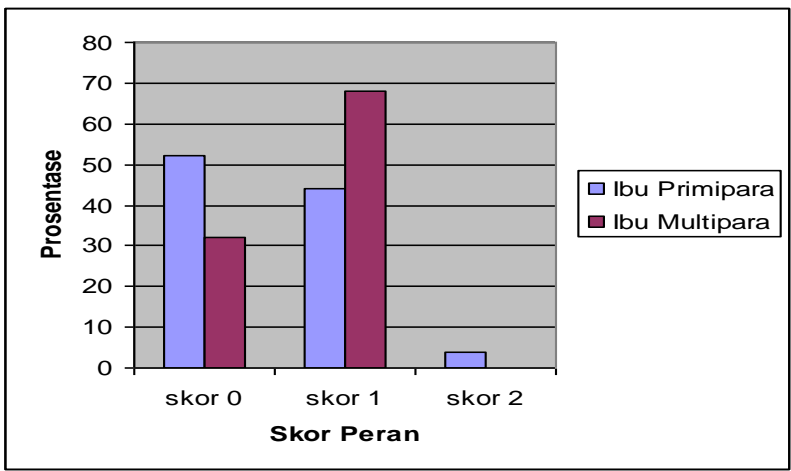


Gambar 3 Prosentase skor aspek response pada ibu primipara dan multípara

\section{d. Speech}

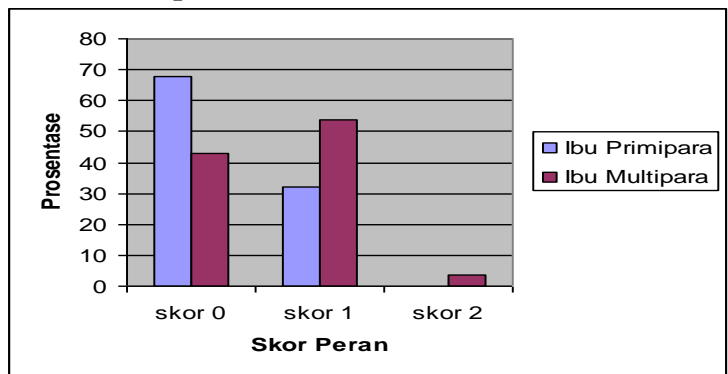

Gambar 4 Prosentase skor aspek speech pada ibu primipara dan multípara

\section{e. Touch}

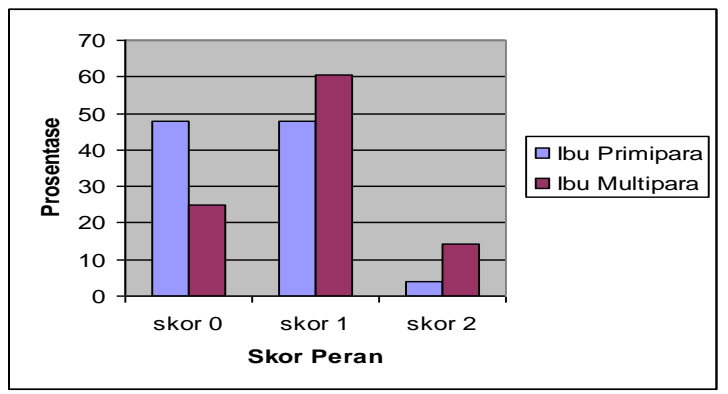

Gambar 5 Prosentase skor aspek touch pada ibu primipara dan multipara

\section{Hasil Uji Hipotesis}

Dengan menggunakan uji statistik Mann Whitney diperoleh nilai signifikansi sebesar 0.036. Nilai tersebut lebih kecil dari nilai $\alpha$ yang ditetapkan sebesar 0.05 , sehingga HO ditolak artinya terdapat perbedaan peran ibu primipara dan multipara dalam pengasuhan bayi baru lahir.

\section{Pembahasan}

A. Peran ibu primipara dalam pengasuhan bayi baru lahir

Pada tabel 2 telah disebutkan bahwa tidak ada satupun ibu primipara yang memiliki peran baik dalam merawat bayi baru lahir. Pada penelitian ini mayoritas ibu (72\%) memiliki peran yang kurang.

Menjadi orangtua merupakan suatu proses yang terdiri dari dua komponen. Komponen pertama, bersifat praktis atau mekanis, melibatkan keterampilan kognitif dan motorik; komponen kedua bersifat emosional, melibatkan keterampilan afektif dan kognitif. Komponen pertama dalam proses menjadi orangtua melibatkan aktivitas perawatan anak, seperti memberi makan, menggendong, mengenakan pakaian, membersihkan bayi, menjaganya dari bahaya, dan memungkinkannya untuk bisa bergerak (Steele \& Pollack, 1968 dalam Bobak, Lowdermilk \& Jensen, 2005). Aktivitas yang berorientasi pada tugas atau keterampilan kognitif motorik ini tidak terlihat secara otomatis pada saat bayi lahir, namun dipelajari orangtua dan dipengaruhi oleh pengalaman pribadi dan budaya (Bobak, Lowdermilk \& Jensen, 2005). Kesiapan ibu menjadi orangtua dapat dipersiapkan melalui proses belajar guna meningkatkan pengetahuan, sikap, dan keterampilan ibu tentang perawatan bayi prematur di rumah.

Ibu primipara adalah seorang yang melahirkan anak pertama kali, oleh karena itu ibu primipara membutuhkan dukungan yang lebih besar dari lingkungan baik dari keluarga, teman maupun petugas kesehatan dalam perawatan dan pengasuhan bayi baru lahir (Bobak et al. 2005: 516). Sesuai dengan penelitian yang dilakukan O'Hara \& Swain (1996) dalam Handoyo et al. (2007) melaporkan sekitar $13 \%$ wanita melahirkan anak pertama mengalami depresi postpartum pada periode tahun pertama pascasalin. Depresi postpartum dapat mengakibatkan terjadinya gangguan psikologis jangka pendek dan jangka panjang. Peristiwa tersebut tidak saja terjadi pada wanita penderita tapi juga pada anak dan anggota keluarga lainnya (Armstrong et al. 2000 dalam Handoyo et al. 2007). Selain itu dapat juga terjadi gangguan hubungan tali kasih ibu dan anak serta kurangnya perhatian ibu dalam merawat, mengasuh serta membesarkan anaknya, kesulitan anak dalam menjalin hubungan sosial dengan lingkungan dan teman sebaya serta konflik perkawinan (Kustjens \& 
Wolke. 2001 dalam Handoyo et al. 2007). Menurut Rubin ada beberapa fase adaptasi peran menjadi orang tua yaitu: ( taking in) fase ini terjadi pada hari $1-2$ hari setelah melahirkan yang ditandai dengan kondisi ibu masih pasif dan tergantung pada orang lain, perhatian ibu tertuju pada kekuatiran terhadap bentuk tubuhnya, ibu memerlukan ketenangan dalam tidur untuk mengembalikan keadaan tubuh ke kondisi normal (taking - hold) fase ini berlangsung 2- 4 hari setelah melahirkan yang ditandai dengan ibu menaruh perhatian pada kemampuannya untuk menjadi orang tua, ibu berusaha untuk menguasai ketrampilan merawat bayi. Selama fase ini sistem pendukung (support) menjadi sangat bernilai bagi ibu primipara yang membutuhkan sumber informasi dan pemulihan fisik secara optimal, (letting - go) fase ini berlangsung hari kelima setelah persalinan dan seterusnya, yang ditandai dengan ibu sudah bisa mengambil tanggung jawab dalam merawat bayi.

Pada tabel 1 terdapat ibu primipara yang masih berada pada rentang usia 15 19 tahun yang merupakan usia remaja. Transisi menjadi orangtua pada masa remaja mungkin sulit bagi orang tua yang masih remaja. Remaja akan mengalami kesulitan dalam menerima perubahan citra diri dan menyesuaikan dengan peran baru yang berhubungan dengan tanggung jawab merawat bayi (Bobak et al. 2005:835).

B. Peran ibu multipara dalam pengasuhan bayi baru lahir

Pada tabel 2 telah disebutkan bahwa ibu multipara memiliki peran dengan prosentase cukup dengan kondisi lebih baik dibanding ibu primipara yaitu sebesar $46,4 \%$.

Komponen psikologis sebagai orangtua, bersifat keibuan atau kebapakan berakar dari pengalaman orangtua saat mengalami dan menerima kasih sayang dari orangtuanya. Keterampilan kognitif afektif menjadi orangtua meliputi sikap yang lembut, waspada, dan memberi perhatian terhadap kebutuhan dan keinginan bayi. Komponen menjadi orangtua memiliki efek yang mendasar pada cara perawatan bayi yang dilakukan dengan praktis dan pada respon emosional bayi terhadap asuhan yang diterima (Bobak, Lowdermilk \& Jensen, 2005). Selain pengalaman dari orang tua juga pengalaman seorang ibu dalam merawat bayi baru lahir berakar dari pengalamannya terdahulu dalam merawat bayi yang pernah dilahirkan.

Pada tabel 1 usia ibu multipara yang berada pada rentang $24-34$ tahun sebesar $71,5 \%$, sedangkan yang berada di rentang usia 35 tahun ke atas adalah sebanyak $28,5 \%$. Hasil penelitian yang menunjukkan peran ibu multipara dalam kategori cukup berkaitan dengan usia yang siap melaksanakan peran sebagai ibu dalam memberikan pengasuhan pada bayi yang baru dilahirkan dengan baik. Sedangkan permasalahan pada usia tua yang dapat mempengaruhi peran seorang ibu dalam pengasuhan bayi baru lahir adalah keletihan dan kebutuhan untuk lebih banyak istirahat.

Ibu multipara adalah ibu yang sudah pernah melahirkan anak beberapa kali tapi tidak lebih dari 5 kali, oleh karena itu pada multipara akan lebih realistis dalam mengantisipasi keterbatasan fisiknya serta akan lebih mudah beradaptasi terhadap perannya dalam pengasuhan bayi (Bobak et al. 2005: 516).

Peran ibu multipara dalam pengasuhan bayi baru lahir yang diukur dengan metoda FIRST menunjukkan nilai cukup, hal ini diantaranya disebabkan oleh karena ibu multipara sudah pernah melahirkan anak sehingga secara psikologis lebih siap menghadapi kelahiran bayi dibandingkan dengan ibu primipara. Pada ibu multipara sudah mempunyai pengalaman dalam pengasuhan bayi sebelumnya sehingga ibu multipara akan lebih mudah beradaptasi terhadap peran sebagai orang tua dalam perawatan bayi baru lahir. 
C. Perbedaan peran ibu primipara dan multipara dalam pengasuhan bayi baru lahir.

Hasil penelitian menunjukkan terdapat perbedaan peran ibu primipara dan multipara dalam pengasuhan bayi baru lahir. Dari masing-masing aspek yang dicantumkan dalam gambar 1 sampai dengan 5 menunjukkan bahwa prosentase skor penilaian yang tinggi didominasi oleh ibu multipara. Prosentase Skor Feeding pada ibu multipara adalah $100 \%$ pada skor 1, skor 1mengandung makna bahwa seorang ibu memiliki kemampuan antara lain jika memberi ASI, ibu berusaha untuk mendekatkan payudaranya ke mulut bayi, tetapi membutuhkan banyak bantuan dan dukungan untuk melakukan hal ini. Jika memberikan susu botol, ibu akan menanyakan "regimen" pemberian makanan dan jam makan bayi; ia membutuhkan lebih banyak bantuan dan dukungan. Kebersihan ibu kurang baik misalnya: ia tidak mencuci tangannya sebelum memberikan ASI dan ceroboh dalam mensterilkan botol susu bayi. Mampu melaksanakan koping pada saat menyusui dan memahami kebutuhan makan bayi. Sedangkan ibu primipara 96 $\%$ memiliki skor 1 .

Pada aspek interest menunjukkan hasil bahwa ibu multipara $50 \%$ mendapatkan skor 1, sedangkan ibu primipara $28 \%$ mendapatkan skor 1 . Skor 1 pada aspek ini ditunjukkan oleh ibu dengan berperilaku : Ibu berkomentar tentang penampakan bayinya, warna rambut, kelopak mata, kulit, bentuk tubuh atau tingkah laku, misalnya menangis, isapan pertama atau rooting. Ibu hanya memperhatikan tentang kepuasan atau ketidakpuasan pemberian makanan dan/atau pola tidur.

Aspek response memberikan gambaran pada kedua responden dengan prosentase tertinggi sebesar $67,9 \%$ pada skor 1 oleh ibu multigravida dan $52 \%$ pada skor 0 pada ibu primigravida. Skor 0 ini menunjukkan terdapat keadaan yang seperti Ibu tidak bereaksi saat bayi menangis. Ia secara persisten berpaling dari bayi, Tidak melihat bayi di tempat tidurnya bayi, Menghabiskan banyak waktu untuk menjauh dari tempat tidur bayi. Ibu akan mendekat ke bayi hanya jika bayi menangis. Akan meninggalkan tidak terjaga dalam waktu lama jika ia tidak menangis.

Skor 1 pada aspek speech memberikan gambaran dari beberapa kondisi di bawah ini dialami oleh ibu yaitu : Bayi digendong dalam posisi yang memungkinkan terjadinya kontak mata. Ibu mungkin tersenyum pada bayi. Ibu mungkin terhambat untuk bercakap-cakap dengan bayi. Ibu mungkin berbicara "dengan bayi" bukan "pada bayi. Pada aspek ini 53,6\% dilakukan oleh ibu multipara dan $32 \%$ pada ibu primipara.

Skor 2 pada aspek touch ditunjukkan dengan kondisi $4 \%$ pada ibu primipara dan $14,3 \%$ pada ibu multipara. Skor 2 ini ditunjukkan dengan kemampuan ibu melaksanakan : Ibu membuat kontak yang sering dengan menyentuh, mengelus, mencium, atau menggendong bayi setelah atau di antara waktu pemberian makan. Ibu menggendong bayi secara vertikal (diletakkan di bahu) sehingga memungkinkan pipi ibu menyentuh wajah bayi .

Teori dan model Maternal Role Attainment diperkenalkan dalam simposium penelitian internasional yang disponsori oleh American Nursing Association (ANA) dan konsil keperawatan Amerika menggambarkan bahwa lingkungan mempengaruhi pencapaian peran maternal. Menurut Mercer menjadi seorang ibu merupakan perjalanan yang luar biasa dari siklus kehidupan wanita, sebab hal itu merupakan suatu proses yang tidak pernah berhenti dan terus berkelanjutan.

Lingkungan yang paling dekat dalam proses pencapaian peran maternal adalah fungsi keluarga, hubungan ibu-ayah, dukungan sosial, status ekonomi, nilai dan 
kepercayaan dalam keluarga serta sumber stressor yang dipandang melekat dalam sistem keluarga. Variabel-variabel tersebut saling berinteraksi satu sama lain dan memberikan pengaruh dalam transisi menjadi motherhood. Bayi merupakan individu yang ada di dalam sistem keluarga. Keluarga dipandang sebagai sistem semi tertutup yang membatasi dan mengontrol perubahan diantara sistem keluarga dan sistem sosial lainnya. Komponen yang paling berpengaruh dalam pencapaian peran maternal terjadi melalui interaksi antara ayah, ibu dan bayinya.

Ibu multipara memiliki pengalaman yang lebih banyak dalam memberikan pengasuhan pada bayi yang baru dilahirkan jika dibandingkan dengan ibu primipara. Proses menjadi ibu sudah lebih dahulu dimiliki, sehingga tinggal mengasah kemampuan yang telah dimiliki.

\section{Simpulan Dan Saran}

Simpulan

a. Peran ibu primipara dalam pengasuhan bayi baru lahir menunjukkan bahwa interaksi antara ibu dan bayi serta kemampuan ibu primipara dalam pengasuhan dan perawatan bayi baru lahir adalah sebagian besar kurang

b. Peran ibu multipara dalam pengasuhan bayi baru lahir menunjukkan bahwa interaksi antara ibu dan bayi serta kemampuan ibu multipara dalam pengasuhan dan perawatan bayi baru lahir dalam keadaan berimbang antara cukup dan kurang.

c. Ada perbedaan peran antara ibu primipara dan ibu multipara dalam pengasuhan bayi baru lahir yang di ukur dengan metoda observasi FIRST.

Saran

Upaya peningkatan peran ibu primipara dalam pengasuhan bayi baru lahir perlu lebih digiatkan. Kerjasama dengan keluarga dapat digunakan sebagai salah satu langkah untuk meningkatkan peran ibu tersebut. Kelas persalinan / prenatal dapat lebih dikembangkan untuk mengantisipasi kemampuan ibu dalam mengasuh bayinya.

\section{Daftar Pustaka}

A. Aziz Alimul Hidayat. 2007.Metoda Penelitian Kebidanan Tehnik Analisis Data. Jakarta: Salemba Medika.

Bobak. 2004. Buku Ajar Keperawatan Maternitas Ed. Ke-4. Alih bahasa Maria A A Wijayarini, Peter I. Anugerah. Jakarta: EGC.

Departemen Kesehatan RI. 2005. Pedoman Pelaksanaan Stimulasi, deteksi dan Intervensi Dini Tumbuh Kembang Anak Di Tingkat Pelayanan Kesehatan Dasar. Jakarta: Direktorat Jenderal Pembinaan Kesehatan Masyarakat.

Handoyo, Hartati, Lutfatul Latifah. 2007. Penerapan skala edinburgh sebagai alat deteksi risiko depresi post partum pada primipara dan multipara. Jurnal Ilmiah Kesehatan Keperawatan. 3(3): 163-171.

Henderson, Christine. 2005. Buku Ajar Konsep Kebidanan. Alih bahasa: Ria Anjarwati, Renata Komalasari, Dian Adiningsih. Jakarta: EGC

Hurlock, Elizabeth. 2000. Psikologi Perkembangan Suatu Pendekatan sepanjang Rentang Kehidupan. Ed.ke-4. Alih bahasa: Istiwidayanti. Soedjarwo Jakarta: Erlangga.

IDAI. 2002. Buku Ajar 1 Tumbuh Kembang Anak dan Remaja. Ed. ke-1. Jakarta: CV SAGUNG SETO

Ida Bagus Gde Manuaba. 1998. Ilmu Kebidanan, Penyakit Kandungan Dan Keluarga Berencana Untuk Pendidikan Bidan. Jakarta: EGC

Indriani (tanpa tahun). Studi Fenomenologi : Pengalaman ibu primipara dengan Kelarga Inti dalam merawat bayi baru lahir di jakarta pusat

WWW:digilib.ui.ac.id/opac/themes/li bri2/abstrakpdf.jsp?id=127197\&loka si... 
Nursalam. 2003. Konsep Dan Penerapan Metodologi Penelitian Ilmu Keperawatan. Jakarta: Salemba Medika

POGI.IBI.IDAI. Bakti Husada. 2007. Pelatihan Asuhan Persalinan Normal Bahan Tambahan Inisiasi Menyusu Dini. Jakarta: JNPK - KR / POGI.

Ronny Rahmann Noor. 2006. Metodalogi Penelitian Dan Rancangan Percobaan. Bogor: IPB

Suharsimi Arikunto. 2002. Prosedur Penelitian Kesehatan -Suatu Pendekatan Praktek. Jakarta: Rineka Cipta

Sugiyono. 2007. Statistika untuk Penelitian. Bandung: CV ALFABETA

Soekidjo Notoatmojo. 2005. Metodologi Penelitian Kesehatan. Jakarta: Rineka Cipta

Sutcliffe, Jenny. 2002. Baby bonding Penerjemah: Riky Nalsya. Jakarta: Taramedia \& Restu Agung.

Stright, Barbara R. 2004. Keperawatan Ibu Bayi Baru Lahir: Alih bahasa: Maria A. Wijayarini. Jakarta: EGC

Utami Roesli. 2008. Asi Eklusif Langkah Awal Menjadi Anak Sehat Setiap Saat http: // Parentingislami. wordppress. Com. 